\title{
Analysis of Dairy and Meat Products in the Republic of Kazakhstan
}

\author{
Aigul Kazkenova ${ }^{1}$, Bakytgul Ainakanova ${ }^{1}$, Svetlana Kuzmenko ${ }^{1}$, Bakyt Yerdenbekova ${ }^{1}$ \& Arailym Kassenova ${ }^{1}$ \\ ${ }^{1}$ Economical science on specialty Management, S. Seifullin Kazakh Agro Technical University, Kazakhstan \\ Correspondence: Aigul Kazkenova, Prospect Pobedy, 62, Astana, 010000, Kazakhstan.
}

Received: February 21, 2015

Accepted: April 23, 2015 Online Published: July 30, 2015

doi:10.5539/ass.v11n19p90

URL: http://dx.doi.org/10.5539/ass.v11n19p90

\begin{abstract}
The purpose of state regulation of agro-industrial complex of Kazakhstan at the present stage is to create the conditions (legal, financial, informational, and infrastructural) to move to the industrial and information technology, the development of cluster structures for the formation of a competitive economy. At the same time, in our opinion, there is still not enough attention paid to stimulate agricultural enterprises (without which it is impossible to maintain a position in the domestic market, and even more to go on the outside); development of constructive relations of social partnership between market participants (network of the enterprises and suppliers, enterprises and education system, enterprises and research institutes, enterprises and the state, etc.); development of competition between market participants.
\end{abstract}

Keywords: Republic of Kazakhstan, analysis, food industry, dairy and meat products

\section{Introduction}

Kazakhstan plans to score a success not only in new technologies, as well as in agriculture. The world experience confirms the global crisis affects the agrarian country not more. The development of the agricultural sector provides the economy with the stable growth of small and medium-sized enterprises, the trade between the regions and the growth of macroeconomic indicators (Zhakipbekov et al., 2014, pp. 261-267; Shertaeva et al., 2014, pp. 16-23; Utegenova et al., 2013, pp. 664-672; Datkhayev et al., 2013, pp. 677-683; Botabayeva et al., 2013, pp. 302-309; Zhumabayev et al., 2013, pp. 36-40).

Expansion and deepening of market relations, as well as solving problems of Kazakhstan's accession to the WTO and becoming one of the 50 most developed countries of the world will inevitably lead the country into the global economy, where the interests of countries at different levels of economic development. Kazakhstan, which has a high potential for the development of agriculture, may be among the world leaders in the production and processing of agricultural products (Zhumagulova, 2009, pp. 344-348).

The country's economic policy leads to positive changes in the economy generally and in the agricultural sector in particular. According to national circumstances and effective reform of socio-economic nature has led to the fact that over the past 10 years of commercial production of meat and meat and dairy products increased by $77 \%$, while the livestock sector of the eastern region is $65.7 \%$ of the gross domestic product of agriculture (Vinnychenko, 2013, pp. 34-39).

Output of Kazakhstan to the international agricultural market is becoming an urgent problem in connection with the forthcoming accession to the WTO and participation in the Customs Union. This will increase competition in the domestic market due to the influx of imported goods and make it difficult to enter the international agricultural market (Vinnychenko, 2006, pp. 43-46).

In a globalized export - is an indicator of the state to achieve the status of an equal participant in international trade and industrial relations. Diversification of the economy in favor of the products of processing industries - a necessary condition for industrial and innovative development of the economy, aimed at the achievement and implementation of its competitive advantages.

Integration of the export policy of the state is determined by the intersection of the objective laws of economic interests and values at the national level. Active export policy is an important part of trade policy in many countries, and Kazakhstan in this issue is no exception (Vinnychenko, 2008, pp. 70-74).

To analyze and evaluate the export potential of the following indicators: real and objectively possible volume of production, its dynamics in recent years and trend changes; real and objectively possible exports, its share in 
total production and trends; a list of contractors in the world market, including potential; exports in terms of export competitiveness and efficiency of foreign trade; the need to import purchases for export production (dependence on imports); market capacity (internal and external) for each type of product, including the potential; market share of producers in the domestic and foreign market for each product, and the potential market share; However, in relation to its main competitors; the level of export competitiveness of the enterprise; share of the costs associated with sales, marketing (including advertising) exports in the value of exports and the possibility of its reduction, as well as a number of other components (Akimbekova, 2011, pp. 100-103).

Competitiveness of the national economy and the strengthening of Kazakhstan's position in the international arena can be implemented through an efficient export policy. The desire of the state to implement access to the international market for agricultural products determines the need for a paradigm shift. Instead of the paradigm export of raw materials we need a new paradigm - a sharp increase in processing agricultural raw materials due to the economic agro-industrial diversification, with a large output of Kazakhstan content and export capacity of competitive advantages in the international market (Nurmagambetov, 2012, pp. 119-124; The project "Development of export potential of cattle meat the Republic of Kazakhstan", 2011).

The indisputable fact is that the structure of domestic exports shows greater dependence on natural resources: the share of mineral fuels, iron, steel and ore accounts for almost $90 \%$ of total exports. Non-primary goods, machinery, equipment and tools together - less than one percent, while the share of the agrarian sector in the foreign market is marked export crops. Public policies adopted to date, scheduled usually outline Kazakhstan's export expansion. However, it is undeniable that the basis for long-term export strategy of Kazakhstan should be the expansion of exports of meat and dairy products with high local content.

Agriculture and food processing industry produces three-quarters of food and a significant proportion of raw materials for light industry, actually determining the standard of living of the population. In this case, the consumption of meat and dairy products supplied for population of Kazakhstan significantly lower than health standards. Hence, the solution of this important problem of the economy is largely dependent on the production and processing of meat and dairy products, from government support and the use of the cluster approach of production, processing and sales in the domestic and foreign markets.

In accordance with the experience of the functioning of agricultural production in the countries with developed market economies to provide the population with high-quality food products of animal origin is carried out only by deep processing, with full use of all components of the raw materials, thus enhancing the competitiveness of products. Currently in the country, many companies use innovative technologies which do not work with the use of primitive equipment and production of competitive goods. As a result, the domestic market is flooded with imported meat and dairy products, so you need to identify priority areas for the formation and development of the dairy industry, taking into account the reduction of losses in the production of high quality products. This task is associated with an increased efficiency of agricultural production, and, above all, livestock, on which the food security of the country (Management in APC, 2007).

Currently, the primary task is to reach the current level of processing of agricultural products. If importers thanks to donations import into the Republic cheap products, the government should, through the establishment of customs duties and equalize them with the prices for the products of domestic producers. Therefore, great importance is attached to improving the mechanism of production and economic relations between the rural household producers and processors of meat and milk, to establish the optimal proportions for the production and sale of food products, the development of economically interconnected branches of agriculture.

These measures will help to organize the complex processing of rural economic production, improve its quality through the use of cheap components of animal and vegetable origin. The proposed theoretical and methodological approaches will contribute to the efficient market mechanisms and the development of dairy industry of the country. Thus, the above-mentioned aspects of the problem identified the relevance of the research topic and its national-economic importance.

\section{Methods}

The dairy and meat products are the important components of food industry in our Republic. As the food industry ensures the food safety of the country, it has an important place in the state's development. Therefore, the price of dairy and meat products are socially significant for the population. 


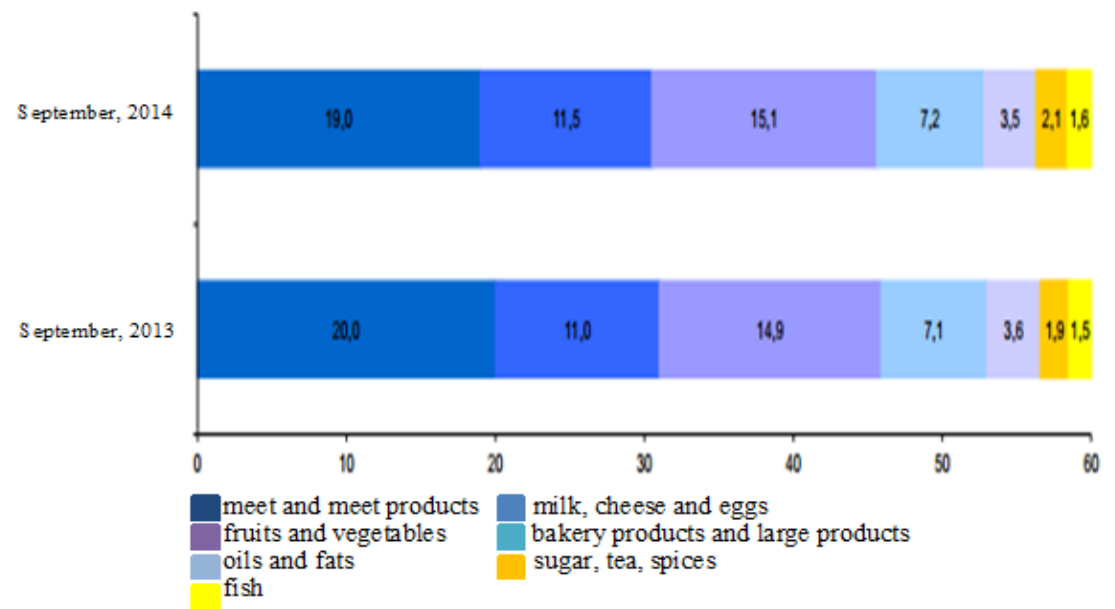

Figure 1. The structure of food basket, in \% (The statistical indicators of socio-economic development of the Republic of Kazakhstan and its regions, 2014)

From figure 1, the meat and dairy products are the $1 / 3^{\mathrm{d}}$ part of the consumer basket. If we are comparing the periods, we can see the meat products decreased by $1 \%$ during the reporting period, and the dairy products increased by $0.5 \%$. The living wage of September 2014 was KZT 20321.

The calculation of statistical indicators of meat and dairy products accounted for the sector of agriculture, forestry and fisheries in accordance with the criteria of Statistics Agency of RK.

Table 1. Price indices in agriculture economy (including the meat and dairy products) in 2014

\begin{tabular}{llllll}
\hline \multirow{2}{*}{ Description } & \multicolumn{2}{l}{ September 2014 to } & Jan-Sept 2014 to Jan -Sept \\
& $\begin{array}{l}\text { August } \\
2014\end{array}$ & $\begin{array}{l}\text { December } \\
2013\end{array}$ & $\begin{array}{l}\text { December } \\
2013\end{array}$ & $\begin{array}{l}\text { September } \\
2013\end{array}$ & \begin{tabular}{l} 
2013 \\
\hline Agricultural
\end{tabular} \\
$\begin{array}{l}\text { production } \\
\text { Crop production }\end{array}$ & 101,0 & 107,9 & 103,9 & 120,8 & 95,6 \\
Livestock products & 99,9 & 113,2 & 102,2 & 113,3 & 90,5 \\
\hline
\end{tabular}

Source: Statistics Agency of RK, 2014, $3^{\mathrm{d}}$ quarter

Table 2. Price index by types of agricultural products

\begin{tabular}{llllll}
\hline \multirow{2}{*}{ Description } & \multicolumn{2}{l}{ September 2014 to } & \multicolumn{2}{c}{ Jan-Sept 2014 to Jan -Sept 2013 } \\
& August 2014 & December 2013 & December 2013 & September 2013 & \\
\hline Wheat & 102,3 & 117,2 & 100,5 & 110,9 & 85,3 \\
Barley & 102,6 & 108,4 & 98,7 & 135,3 & 91,7 \\
Oats & 100,1 & 99,7 & 99,5 & 123,6 & 99,8 \\
Buckwheat & 100,1 & 80,3 & 75,3 & 52,4 & 73,9 \\
Potatoes & 94,7 & 109,3 & 103,3 & 93,0 & 100,4 \\
Cattle & 100,2 & 101,0 & 99,4 & 134,6 & 97,2 \\
Horse & 99,8 & 102,3 & 101,9 & 133,5 & 101,6 \\
Sheep & 100,3 & 101,9 & 103,6 & 163,9 & 104,4 \\
Pig & 99,6 & 109,1 & 112,8 & 118,1 & 107,5 \\
Bird & 101,9 & 114,6 & 118,7 & 115,3 & 105,1 \\
Raw milk & 101,1 & 105,5 & 112,6 & 128,0 & 109,1 \\
Eggs & 93,6 & 73,5 & 91,5 & 81,6 & 97,3 \\
\hline Source: Stats & & & & \\
\hline
\end{tabular}

Source: Statistics Agency of RK, 2014, $3^{\mathrm{d}}$ quarter 
Compared with the previous year (September, 2013) the price index in animal products was 124.6 points, what confirmed the price increased for $24.6 \%$, which is 11.3 points higher than the crop production. The increase in this sector for 9 months of the reporting period was $2.5 \%$ in comparison with the base period.

Table 2 showed us the structure of price indices which demonstrated the state of the products we are interesting in.

The table showed us the increase of prices was fixed on whole structure of consumer basket on agriculture.

By product, the price of milk has an increasing trend. The milk increased in price by $1.1 \%$ within of 1 month and by $12.6 \%$ - within of 1 year exceeded.

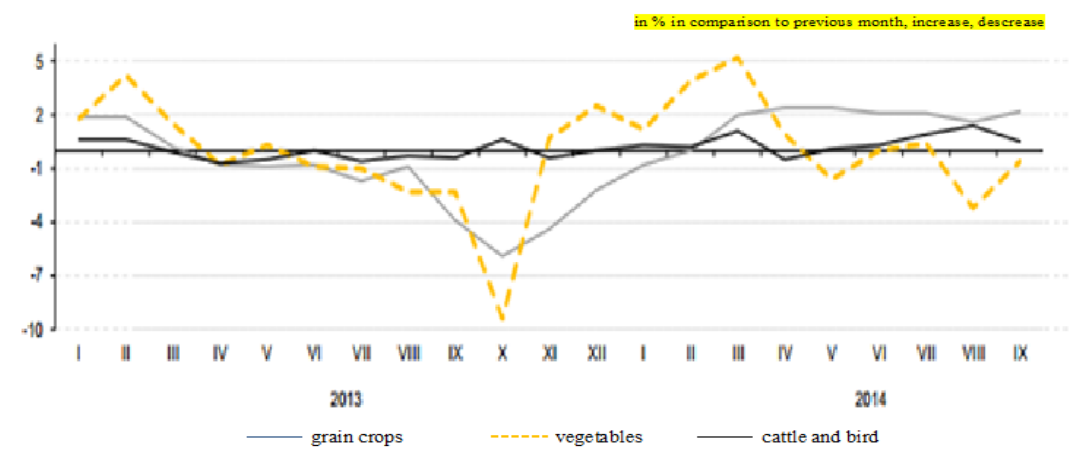

Figure 2. Dynamics of changes in grain production, vegetables, cattle and poultry (The statistical indicators of socio-economic development of the Republic of Kazakhstan and its regions, 2014)

The dairy and meat products determine the employment of the country people, which is a critical factor in reducing its poverty. Figure 3 shows only $54 \%$ of enterprises operate in the industry.

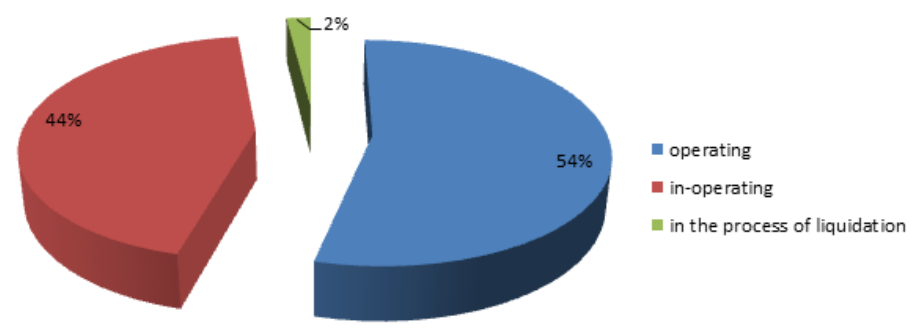

Figure 3. Analysis of registered body corporate in agriculture, forestry and fisheries (The statistical indicators of socio-economic development of the Republic of Kazakhstan and its regions, 2014)

12845 bodies corporation in agriculture, forestry and fisheries were registered for October $1^{\text {st }}, 2014.6896$ enterprises from whole amount are operating which are 54\%. 258 enterprises are in the process of liquidation which make $2 \%$, and $44 \%$ of existing enterprises.

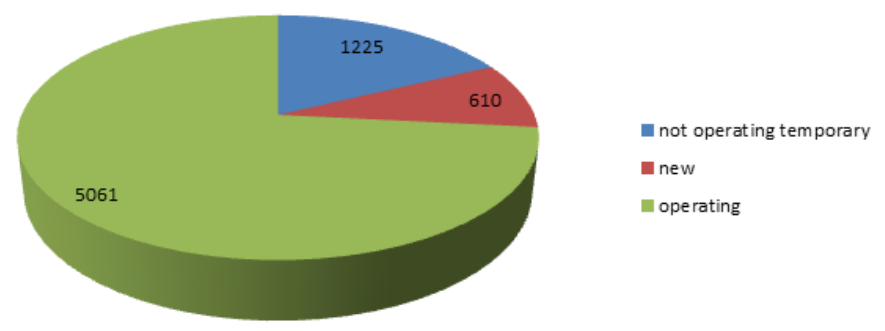

Figure 4. Analysis of operating body corporate in agriculture, forestry and fisheries (The statistical indicators of socio-economic development of the Republic of Kazakhstan and its regions, 2014) 
Figure 4 shows us 5061 enterprises out of operating 6896 which make 73.4 of the unit weight. Not operating temporary enterprises are on the $2^{\mathrm{d}}$ place, which make $17,8 \%$. And $8,9 \%$ of the unit weight are new enterprises.

The statistical indicators of the functioning of the dairy industry in Kazakhstan suggest the implementation of food safety standards in the first approximation, i.e., of the total amount of product produced. But in its structure there are significant disproportions, the replacement of many types of imported dairy products in the domestic market is still unrealistic, since its production is not enough in quantitative terms, and its can be substitutes only goods of the lower price segment in the quality.

As Kazakhstan entries into the Customs Union it is very necessary to research this industry and to solve the current unsolved questions.

Kazakhstan is like the other developing markets, but there are certain features. The special features of the dairy industry can be attributed the manufacturers face a huge deficit of raw materials at the present.

There are not the large farms in our Republic like in the Europe. About $95 \%$ of milk is collected from the backyard, which affects the cost and quality of raw materials. The raw milk in Kazakhstan today is one of the most expensive in the world.

The price of milk as raw material commensurate with those in Japan and South Korea, which, of course, has a negative impact on the competitiveness of our dairy products within the market, and abroad. This is a serious problem that is on the surface for several years now.

Many efforts applied already, including by the state. However, apparently, these efforts are insufficient. In addition to the problem of raw materials, there is another serious problem - the level of consumption of milk which is very low in Kazakhstan. For example, the level of milk consumption in Finland is on average from 150 to 170 liters per capita per year. But in Kazakhstan, there is about 36 liters only, according to official data. At the same time, more than half consumed milk - milk "from the street" which is not safety by repeated warnings of medic (Kazakhstan cannot join the market of Custom Unit with the milk product, 2010).

The power of dairy processing plants are filled by $35-45 \%$; the number of dairy companies use leasing to update equipment is less than $1 \%$; the number of companies that have established ISO-standards is $3 \%$, only $3-4 \%$ of businesses are covered by country credit associations.

In Kazakhstan, only $20 \%$ of agricultural output consists of recycled materials, while the structure of world agriculture products according to the WTO consists of $80 \%$ of the processed products, and only $20 \%$ is the agricultural raw materials.

Under the conditions of joining the WTO it is necessary to rationalize public funding producers according to the cluster model of development. To arrange this, as the experience of developed countries confirmed, it is necessary to change forms of management in agriculture, building on strong cooperative associations or large agro formation.

The historical specificity of management in the field of milk production is the major of the raw milk is produced in developed countries by the farms, united in cooperatives, which are all over the world the primary producers, processors and distributors of milk.

Systematizing the experience of the United States, Finland, the Netherlands, we can conclude the modern development of cluster structures in the manufacture of dairy products:

- Are in the form of economic co-op which has developed in the ascending process chain, or there is an independent generating a large company that supports long-term business relationships with a network of cooperatives (consisting of large, medium, small cooperative societies);

- Have in their production, as the main products of high quality and value-added products. As a rule, its occupy a market niche. To develop some innovative products it's have in its company or its engage in close cooperation with research centers that offer ideas and technologies for the production of modern products, enrichment of nutrients and bio-additives;

- Have an active and visible support of the public sector in matters of science and the training of new personnel for the sector (The strategic plan of the Ministry of Agriculture of the Republic of Kazakhstan, 2014; Porter, 1990, p.78). 


\section{Discussion and Results}

The equipment for enterprises processing the dairy products, are updated only by $50 \%$, it is necessary to install a modern line of packing and vacuum packing. The adoption of ISO system is advisable for sure competition in processing plants.

In vocational schools and universities there are no skilled and competitive specialists who may work on automated lines with program management. The investment in training livestock (herd's renewal, selection) and farmers (conditions of stock keeping and feeding, the hygiene standards, storage of feed, etc.) are requested.

The purpose of state regulation of agro-industrial complex of Kazakhstan at the present stage is to create the conditions (legal, financial, informational, and infrastructural) to move to the industrial and information technology, the development of cluster structures for the formation of a competitive economy. At the same time, in our opinion, there is still not enough attention is paid to stimulate agricultural enterprises (without which it is impossible to maintain a position in the domestic market, and even more to go on the outside); development of constructive relations of social partnership between market participants (network of the enterprises and suppliers, enterprises and the education system, enterprises and research institutes, enterprises and the state, etc.); development of competition between market participants.

Effective functioning of rural economic units depends on the level of specialization and concentration of production, developing under the influence of two trends: the depth of division of labor, promote a more narrow specialization; seasonality, land resources and interdependence of crop and livestock sectors, which necessitate the development of processing enterprises. The transition to large-scale production, innovation strategy of its development is the most important means of ensuring the stabilization of the growth of agricultural production.

At the same time there are problems that require a speedy solution, namely a high degree of wear of process equipment, the lack of effective technologies for processing raw materials, underutilized capacity, especially milk and meat, low-quality raw materials supplied by the farms of the population. To improve the efficiency of milk production must increase production of competitive products, capacity utilization due to the supply of raw materials.

The studies found that the level of maintenance of the population of Kazakhstan meat and meat products of own production with the recommended evidence-based database software is $61 \%$, milk and milk products - $68.4 \%$. Hence, there is a need to develop proposals and recommendations to increase livestock production based on specialization, concentration of specific regions of Kazakhstan.

Further growth of livestock must be due to the industry's ability to realize the comparative advantages that have appeared over the years of independence. These include: the rise of the welfare of the population, caused a significant increase in demand for goods and products in the local market, and potential export opportunities in the long term. The need to address the problem of precisely this angle is explained by the fact that at present the export of livestock products is low, but the potential of agro-industrial complex of Kazakhstan is such that allows him to fight for equal employment of free segments in the global market of agricultural products.

Animal husbandry complex should be considered not only from the perspective of the supplier of meat and dairy products for the domestic market, but also as a promising sub-sector, which provides the basic raw material industries such as light industry, textile, construction, engineering and other industries. The livestock sector is a waste-free production, which uses not only the skin and hair, but also horned ungulates, endocrine enzymatic and other raw materials, the resulting slaughter.

For the effective functioning of rural economic units required to comply with the following conditions: economic system must meet the science-based management of production, market conditions and the needs of the population, especially in livestock production. Procurement and processing enterprises should pay its producers at prices set by taking into account the cost recovery and obtaining a certain level of income, but not less than $15-20 \%$ of profitability. Payments in the amount of $40 \%$ of the cost of purchased products must be made within 10 days after signing the contract. The final payment for the products is carried out after the completion of its implementation.

For solving these problems there were proposed the following activities: to organize dairy farms with highly productive dairy herd; to organize deep processing of milk and other animal products; to create a specialized enterprise for the production of meat. Expected results: an increase in the production of competitive livestock production; food security, growth in exports competitive livestock production.

To improve the efficiency of production of meat and milk is necessary to introduce intensive and resource-saving technologies, the creation of large specialized farms for breeding and fattening cattle. There is a proportional 
relationship between the indicators of profitability of production and the size of farms. In larger farms due to the rational use of labor resources, the use of advanced technologies, progressive forms of operation, cost-effective production and higher than the fine.

To stimulate rural economic units and households are invited to pay subsidies for actually sold products to processing plants, as well as on the market. Payment must be made subject to identification services slaughterhouses and processing plants, on the open market - within the quota of regional, district authorities, determined on the basis of zoo technical standards and quality of products sold.

Greater use of the patent system of taxation of consumer cooperatives for the implementation and processing of livestock products produced by peasant households (members-shareholders cooperative), which will increase their effectiveness.

Companies involved in the processing of meat and meat products, milk and cheese production, manufacture of prepared animal feeds, not have to pay value added tax. This will reduce the cost of produced and sold livestock products. Thus, the development of the industry milk and meat production through the use of scientific and technological progress is one of the main ways of increasing the economic efficiency of production of meat and dairy products.

The main constraints on the development of export potential of meat products are unstable epizootic situation (violation of veterinary-sanitary norms in the content and slaughtering): lack of industrial fattening and standard lots of meat products, the low proportion of breeding cattle beef $(1 \%)$ in the general population cattle.

Studies have shown that the development of investment policy in the agricultural sector should be taken into account, on the one hand, especially of capital in this sector, on the other - regional peculiarities. Investment policy in the agricultural sector, consistent with the state, is able to provide a revival in investment activity, while reducing inter-regional disparities. In general, it should be based on: the adoption of protectionist measures to revive domestic production - a mechanism to encourage investment in the national production of surplus funds of domestic business; strengthening certification regime at the customs borders; system coordination significant disparities in the prices of industrial and agricultural products.

Overcoming the shortage of investment resources for the development of meat and dairy, food and agro-industrial complex of Kazakhstan as a whole requires the mobilization of all sources, both internal and external. Active use of internal resources will require time required to restore the financial and credit system of the state budget. Therefore, in the short term especially important to attract foreign loans and investments.

Increase in the proportion of borrowed funds indicates a decline in the financial condition of agricultural enterprises and the dairy industry, increasing the degree of financial risk, as well as the active redistribution of income from creditors to the debtor company. Unevenness in revenues characterizes the features of material incentives and financing company's valuation of their resources and costs. In addition, the need for seasonal stocks in agricultural enterprises is a need for additional investment.

Sustainable financing of agricultural production can be accomplished through the creation of reserve funds and the involvement of credit and investment resources. The impact of industry characteristics on the organization of production is reflected in the content of financial relations - the nature of the cash generated funds and directions of their use, the system of income distribution, relationships with the various levels of national finances.

It is proposed to develop a two-channel system of foreign investments: international loans and foreign direct investment. Preference should be given to direct investment, with significant advantages over other forms of borrowing economic: they are a direct source of capital for investment in the production of goods and services, ensuring the involvement of the world of technology, advanced management and marketing techniques; do not increase the country's external debt; most conducive to the integration of the national economy due to a variety of industrial and scientific-technical cooperation. The size of benefits is based on the standard scale, depending on the volume of investment in fixed assets and the priority sectors of the economy.

Given that the main source of innovation development of agriculture is the income necessary analysis shows that to increase the existing amount of state support of agricultural producers in the form of subsidies of up to $10 \%$, which will increase the efficiency of production and put in equal economic conditions of the Customs Union Belarus, Kazakhstan, Russia.

\section{Conclusion}

At the same time, in our opinion, there is still not enough attention paid to stimulate agricultural enterprises (without which it is impossible to maintain a position in the domestic market, and even more to go on the 
outside); development of constructive relations of social partnership between market participants (network of the enterprises and suppliers, enterprises and the education system, enterprises and research institutes, enterprises and the state, etc.); development of competition between market participants.

\section{References}

Akimbekova, H. W. (2011). According to the materials of the Republican Scientific and Practical Conference (20 Years of the socio-economic development of the agro-industrial complex of Kazakhstan), May 20, 2011. Problems of agricultural market, 100-103.

Botabayeva, R., Shertaeva, C., Blinova, O., Datkhayev, U., Shopabaeva, A., Zhanabayev, N., \& Zhakipbekov, K. (2013). Methodical approaches to a strategy of diversification to advance domestic production of medicines. Life Sci. J., 10(12s), 302-309.

Datkhayev, U., Shopabayeva, A., Zhakipbekov, K., Yermekbayeva, D., Orazbekov, E., \& Turgumbayeva, A. (2013). Basic aspects of the organization of the pharmaceutical industry. Life Sci. J., 10(7s), 677-683.

Interview with the Director of SP (Molservice) Sergey Chepurko. Kazakhstan cannot join the market of Custom Unit with the milk products. Retrieved December 8, 2010, from http://www.meta.kz/468430-kazakhstan-ne-mozhet-vyjjti-na-rynok-tamozhennogo.html

Michael, E. P. (1990). The Competitive Advantage of Nations. Harvard Business Review (p. 78).

Nurmagambetov, K. K. (2012). Key factors constraining the development of the dairy industry of the Republic of Kazakhstan. Bulletin of Science Kazakh Agro-Technical University S. Seifullin, 4(75), 119-124.

Shertaeva, C., Tulemissov, S., Botabayeva, R., Blinova, O., Mamytbayeva, K., Zhanabayev, N., ..., Zhakipbekov, K. (2014). Improvement of medicine provision of patients with a chronic obstructive lung illness on the basis of pharmaceutical and economical investigations. Life Sci. J., 11(9s), 16-23.

The project "Development of export potential of cattle meat the Republic of Kazakhstan". (2011). JSC "National Holding" KazAgro".

The statistical indicators of socio-economic development of the Republic of Kazakhstan and its regions. (2014). Collection of the Statistics Agency of RK.

The strategic plan of the Ministry of Agriculture of the Republic of Kazakhstan for 2014 - 2018 years. Retrieved December 18, 2014, from http://mgov.kz/ministerstvo/strategicheskij-plan/

Utegenova, G., Blinova, O., Shertaeva, C., Tulemissov, S., Sapakbay, M., Umurzakhova, G., \& Zhakipbekov, K. (2013). About the standards of development and the placement of pharmacy network in the Republic of Kazakhstan. Life Sci. J., 10(12s), 664-672.

Vinnychenko, B. C. (2006). Improving the efficiency and competitiveness of agricultural products. Society. Inform. analyte. Bull. Ministry of Culture and Information (pp. 43-46).

Vinnychenko, B. C. (2008). The development of market forms of management in agricultural production in Kazakhstan. Problems of agricultural market, 1, 70-74.

Vinnychenko, B. C. (2013). Improvement of the economic mechanism in the agricultural sector of Kazakhstan at the present stage. New University, Series (Law and Economics), 3, 34-39.

Zhakipbekov, K., Kaukhova, I., Datkhayev, U., Sakipova, Z., Yeraliyeva, L., \& Datkhayeva, G. (2014). Key Aspects of Pharmaceutical Engineering in Engineering Companies' Activity. Global Journal of Pharmacology, 8(2), 261-267.

Zhumabayev, N., Makhatov, B., Makhatova, A., Magay, T., Zhakipbekov, K., Sapakbay, M., \& Makhatova, B. (2013). The use of mathematical methods of analysis in the pharmaceutical area of Kazakhstan. Life Sci. J., $10(10 \mathrm{~s}), 36-40$.

Zhumagulova, A. K. (2009). The main way of development of healthy competition in the meat processing industry (pp. 344-348). Proceedings of the international scientific-practical conference dedicated to the 70th anniversary of the Doctor of Economics, Professor BG Zhunusova. Kokshetau: KIEM.

\section{Copyrights}

Copyright for this article is retained by the author(s), with first publication rights granted to the journal.

This is an open-access article distributed under the terms and conditions of the Creative Commons Attribution license (http://creativecommons.org/licenses/by/3.0/). 